\title{
Using biomass for pig iron production: a technical, environmental and economical assessment
}

\author{
G. Fick, ${ }^{1,2}$ O. Mirgaux, ${ }^{1}$ P. Neau, ${ }^{2}$ F. Patisson ${ }^{1}$ \\ 1: Institut Jean Lamour, Labex DAMAS, CNRS, Université de Lorraine, France.
}

2: Saint-Gobain PAM, Pont-à-Mousson, France.

Corresponding author: F. Patisson

Address: Institut Jean lamour

Parc de Saurupt

54011 Nancy

France

fabrice.patisson@univ-lorraine.fr

$\begin{array}{ll}\text { Telephone: } & +33383584267 \\ \text { Fax: } & +33383584056\end{array}$

\begin{abstract}
The classical route for iron- and steel-making today is based on massive use of fossil coal, which is responsible for most of the large $\mathrm{CO}_{2}$ emissions of the steel industry. Biomass, as a renewable carbon resource, is a good candidate to substitute for fossil coal and even partial substitution could lead to a significant reduction in $\mathrm{CO}_{2}$ emissions. Depending on the type of biomass, its processing, and the way it is used in the iron making process, many different scenarios may be considered. Those scenarios should be evaluated and compared from technical, environmental, and economical points of view in order to figure out the best options. The case of a real pig iron plant located in the North East of France was investigated. First, we checked the relevance of various biomass options on the basis of the biomass availability around the plant and of the technical requirements of the processes. Then, we carried out a screening life cycle assessment focusing on global warming impacts and following a cradle-to-gate approach. Different biomass-based pig iron production scenarios were compared. The results showed that for a $20 \%$ substitution of biomass for coke, around $300 \mathrm{~kg}$ of CO $\mathrm{CO}_{2}$-equivalent per ton of pig iron produced could be saved, which represents a reduction of $15 \%$ in the total greenhouse gas emissions. Finally, a brief economic evaluation of the resulting scenarios was performed.
\end{abstract}

Keywords: Biomass, pig iron, ironmaking, carbon footprint assessment, life cycle assessment, resource, coal, coke, blast furnace

\section{Introduction}

The steel industry, responsible for more than $5 \%$ of the anthropogenic $\mathrm{CO}_{2}$ emissions worldwide, has started to search for solutions to reduce its carbon footprint [1]. In Europe, since 2005, European commission has been imposing a $\mathrm{CO}_{2}$ policy under the form of quotas: high $\mathrm{CO}_{2}$-emitting industries have to pay for the quantities of $\mathrm{CO}_{2}$ they emit above their allowed quotas. From 2013 to $2020, \mathrm{CO}_{2}$ allowances should be significantly reduced to make these industries improve their carbon management. In the case of iron and steel industry, the main production route uses great quantities of fossil coal - turned into coke - which is the main source of the $\mathrm{CO}_{2}$ emissions of the route. As most processes are rather optimized in terms of fuel consumption, reducing $\mathrm{CO}_{2}$ emissions today means searching either for breakthrough technologies or for $\mathrm{CO}_{2}$-lean fuels, which points to biomass. Indeed, biomass is considered to be $\mathrm{CO}_{2}$ neutral as long as the same amount of biomass burnt is planted back. Besides, several processes in the iron-making route could easily accept biomass with very few 
modifications, which is a decisive advantage. Such an alternative is investigated in the present paper, for an actual pig iron plant located in Lorraine region, in the North East of France.

The plant considered produces pig iron from iron ores, mainly made of iron oxides, using a so-called "first fusion" route based on three main processes: the coking unit, the sintering unit and the blast furnace. The coking unit consists of a series of ovens where fossil coal is pyrolysed at temperatures up to $1000{ }^{\circ} \mathrm{C}$. The solid product is called coke and its carbon content is about $90 \%$. In the sintering unit, iron ore fines, coke and anthracite fines are mixed up, granulated and fired to form solid lumps of sintered iron ore. Finally, in the blast furnace, coke is burnt and gasified generating a high temperature and CO-rich gas. This highly reducing gas reduces the sintered iron ores to produce pig iron (liquid iron saturated in $\mathrm{C}$ ) and $\mathrm{CO}_{2}$.

All these processes could accept biomass for a partial coke or coal substitution. In this context, several substitution scenarios may be considered, depending on the nature and the origin of the biomass, the way it would be used in the process and whether it would need a pretreatment or not to fit the requirements in terms of chemical and physical properties. Once the acceptable biomass-based scenarios are selected, their greenhouse gas (GHG) footprint can be compared together and compared to the classical route to check their environmental viability. For the present study, only GHG emissions were considered, but further work could naturally be extended to a full Life Cycle Assessment (LCA).

\section{Identification of the alternate scenarios}

The fuels recognized as biomass fuels according to European Commission [2] can be divided into four main categories: (i) woody biomass and by-products of the wood industry: wood lumps, wood chips and all other products of the wood industries (sawdust, sawmill wastes...); (ii) products of the farming sector: energy crops (willow, miscanthus, corn...) as well as crop residues (straw, bagasse, hulls...); (iii) organic by-products of the industry: such as papermilll sludge, or wastes from the food-processing industry (FPI); (iv) organic wastes: common wastes, farm effluents or other urban wastes (sewage sludges). These products have very different origins and their physical and chemical properties will therefore significantly differ from one to another.

As iron production is a complex process, biomass products introduced should fit precise chemical and physical requirements. For this reason not all the biomass fuels listed above are suitable for use in the process of iron production. We first established which of those biomass fuels could fit the technical requirements for a fossil fuel substitution.

\section{Selecting raw biomass from technical requirements}

There are basically three different possible locations for biomass use in the iron-making route: in the blast furnace, in the coking plant, or in the sintering unit.

The blast furnace is a quite robust system that can work with a lot of different loads, provided some requirements concerning the physical and chemical properties of the loaded matters remain fulfilled. First the process requires a great amount of carbon input (around $430 \mathrm{~kg}$ of $\mathrm{C} / \mathrm{t}$ of liquid iron), which can be introduced in two ways: either loaded as lumps at the top with the sinter, or injected as powder with hot air at the tuyeres in the lower part of the furnace.

When loaded at the top, like coke lumps are in the normal practice, the substitute is expected: to supply heat through carbon partial combustion, to be a good reducing agent (as carbon or as carbon monoxide), to bring carbon as an alloying element (pig iron contains around $4 \%$ of carbon, stemming from the coke), to create a permeable support, that lets the liquid iron and 
slag flow down and the gases flow upward, and that is able to support all the loads above. Thus, the substitute should present a high LHV (Lower Heating Value), a high carbon content (for reducing and alloying properties), and good mechanical properties (mechanical strength and sufficient size). For example, charcoal fits these requirements and is already used in small blast furnaces in Brazil, allowing up to $100 \%$ replacement of the coke. In bigger blast furnaces however, because of the lower mechanical strength of charcoal, only partial substitution up to $20 \%$ can be considered [3].

When injected at the tuyeres, like PCI (Pulverized Coal Injection) is in the normal practice, the substitute should have similar high LHV and carbon content as well as the ability to be easily pulverized. It should thus be a gas, a liquid with low viscosity or a powder. In addition, its injection should be constant and homogeneous. Finally, a few elements are considered harmful to the process such as heavy metals and phosphorous, which would get in the liquid iron and would alter its mechanical properties once cooled down. Alkali metals and zinc content of the substitute should also be very low as they can reduce the performance of the process and even damage it. Several authors considered the injection of pulverized biomass in the form of powder. They suggested that no more than $25 \%$ of the coke should then be replaced with charcoal fines at tuyeres in order to maintain the productivity of the blast furnace and the quality of the iron produced $[4,5]$.

At the coking plant, a partial substitution of raw biomass for coke, or of charcoal for coal, in the coke oven load is possible if the substitution ratio does not exceed $5 \%$ [6,7]. The produced coke is often called bio-coke. Beyond this limit of 5\% severe effects on the properties of the coke could occur. However, in the Lorraine case considered here, the company does not produce its own coke and buys it from other coke producers, so this option was considered beyond the scope of our study and was not investigated further.

At the sintering unit, coke and anthracite fines are mixed with iron ores. A biomass substitute for those materials would have to respect the following requirements in terms of chemical properties: high LHV, low volatile matter content, low ash and harmful element content; and physical characteristics: size between 1 and $10 \mathrm{~mm}$. Charcoal fits those requirements. According to Lovel [8] charcoal substitution for coke is possible, causing increased production rate but also reduced tumble index, depending on the substitution rate. Thus a compromise has to be found between production rates and the mechanical properties of the sinter [9].

Table 1 summarizes the usual properties of the fossil fuel used at the sintering unit and at the blast furnace and compares those to the properties of different raw biomass feedstocks [1012]. As a first conclusion, raw biomass does not fit the expected requirements neither for the sintering plant nor for the blast furnace, mainly because of its high moisture content and physical properties (size and/or mechanical strength). It is thus necessary to pretreat the biomass to make it fit the requirements of the sintering unit or the blast furnace. Biomass such as sewage sludges or corn stalk have very high ash or alkali content, which make them inappropriate for the considered processes. For this reason they were not considered longer in the present study.

\section{Choosing the pretreatments}

Biomass pretreatment mainly aims at increasing the specific energy content of the biomass. Pretreatment can be thermal or biological.

\section{Thermal pretreatment}

Thermal treatment includes torrefaction, carbonization and fast pyrolysis. The operating principle is the same for the three processes and consists of a pyrolysis: heating biomass in 
(almost) absence of oxygen, which produces three distinct phases, respectively called char (solid), tar or bio-oil (liquid) and syngas (non condensable gases). The product distribution among the three phases depends on the operating parameters, mainly sample size, residence time and temperature. At low temperatures $\left(250\right.$ to $\left.350{ }^{\circ} \mathrm{C}\right)$ and medium residence time (15 to $30 \mathrm{~min}$ ) biomass is torrefied, producing a solid residue with high weight yield. At temperatures around 400 to $500{ }^{\circ} \mathrm{C}$ and longer residence time, the process is called carbonization (slow pyrolysis) and the main product is char. At higher temperatures, short residence time (around 1s) and for small biomass particles, the process is called fast pyrolysis. Further depending on the operating parameters and the adjunction of oxygen or not, fast pyrolysis can be divided into two different processes: fast pyrolysis for bio-oil production and gasification for syngas production. The average yields of each phase for each process are listed in Table 2, from data by $[13,14]$.

Fast pyrolysis for syngas production was not considered here because of the gaseous nature of the product. Indeed, the blast furnace requires a constant and homogeneous supply of fuel and a gaseous injection would require a storage facility between the pyrolysis process and the blast furnace. For security and economical reasons - the plant considered is located in a city such a storage facility is not possible.

Therefore of these four thermal processes, only three were retained: torrefaction, carbonization (slow pyrolysis), and fast pyrolysis for bio-oil production. Concerning the torrefaction process and the lack of related data, we undertook a limited specific study to check its viability. We used an existing process based on a heating screw conveyor to torrefy wood samples for $15 \mathrm{~min}$ at various temperatures from 270 to $500{ }^{\circ} \mathrm{C}$. Temperatures above $350{ }^{\circ} \mathrm{C}$ exceed the usual torrefaction temperatures, but as the residence time remained short, those experiments can still be considered like torrefactions. The composition of the resulting products was then precisely analysed. The results were used to simulate the behaviour of torrefied biomass in the blast furnace using a blast furnace simulation software available at the company, called MMHF. Those experiments and simulations showed that when the temperature of torrefaction was pushed over $400{ }^{\circ} \mathrm{C}$, the LHV of the produced torrefied wood approached 26 to $27 \mathrm{MJ} / \mathrm{kg}$. Such values would fit the requirements.

Concerning the fast pyrolysis process to produce bio-oil, the low heating value (below 18 $\mathrm{MJ} / \mathrm{kg}$ ) of the bio-oil obtained has to be noticed. Of course, it could be possible to refine it to get a more energetic product, but we discarded such upgrading for economical reasons.

\section{Biological processes}

Biological processes break down the biomass in absence of oxygen using bacteria or yeasts that turns the biomass into a liquid phase to produce bio-fuel or biogas. These processes are usually more adapted to high moisture and/or high sugar containing biomasses but not for lignocellulosic biomass such as wood. As previously explained, gaseous products cannot be considered here. Hence biomass with high moisture content that produces biogas, such as manure and sludges, were not evaluated.

\section{Assessing the demand}

The company has defined a target of $20 \%$ reduction in $\mathrm{CO}_{2}$ emissions. Therefore, a partial biomass substitution for the coke would suffice. Although the small Brazilian blast furnaces do already use $100 \%$ charcoal as carbon feed, the context is different. We considered typically that $20 \%$ of the coke is to be replaced. Since the plant produces around $500 \mathrm{kt}$ of pig iron per year, with an average coke consumption of $470 \mathrm{~kg}$ per ton of pig iron produced, thus $47 \mathrm{kt}$ of coke should be replaced annually. A replacement ratio must be calculated for each 
biomass considered. This ratio can be defined as the amount of coke that can be replaced with a ton of a biomass product. In the case of the blast furnace, since coke is consumed both for energy and material needs, the replacement ratio is not just based on LHV. We used again the blast furnace simulation software MMHF for calculating it. At the sintering plant, the replacement ratio was estimated on the basis of the work of Lovel et al. [8] and on the quantity of the anthracite used in the plant. Table 3 lists the replacement ratios obtained. One can note the poor replacement ratio of bio-oil resulting from its low LHV.

Finally, the biomass needs for replacing $20 \%$ of the coke at the blast furnace are reported in Table 4. Concerning the two bio-oil cases, feeding such large quantities of biomass is certainly technically too much, but the figures were kept to allow the same base of comparison. At the sintering plant, the fossil fuel demand is quite low (around $50 \mathrm{~kg} / \mathrm{t}$ of sinter) and we considered that of coke and anthracite fines only anthracite fines would be replaced (around $50 \%$ of the energetic input) with biomass. Indeed, the coke fines, a residue of the use of coke in the blast furnace, have to be used at the company's sintering plant. The biomass need for sintering plant would therefore be small compared to the other scenarios. Thus, Table 4 only shows the demand for blast furnace substitution.

Beyond the Lorraine plant of the company, we also considered cases for a broader use of biomass for steelmaking, either extending the area or increasing the substitution rate, as suggested by Norgate [15]. Thus, Table 4 also gives the figures for Europe - with $271.5 \mathrm{Mt}$ of steel and iron produced each year - and for 20 and 50\% substitutions.

\section{Checking the local availability}

Considering both the relatively high biomass needs of the plant and the issue of biomass transportation, the biomass availability in the neighbourhood of the plant is a matter of prime importance. The following paragraphs investigate the actual availability of each kind of selected biomass.

\section{Wood}

French forest is the largest in Europe covering more than 13 Mha [16]. Its annual growth represents about $50000 \mathrm{kt}$. Yearly, $30000 \mathrm{kt}$ of the French forests are cut for lumber and only $18000 \mathrm{kt}$ of these would really be used as lumber [17]. However, it is very unlikely that this resource could ever be used for iron making needs, which would rather require a low-value woody biomass resource, like that used for power production. We thus focused only on the wood residues usually left on the ground and on the waste from the wood industries. Regarding the latter, the totality of the feedstock is already used by other industries: energy production, production of particleboards or charcoal, and paper mills. Regarding the former, exporting the residues would cause antagonistic effects: it would increase the forest yield but it would also reduce the carbon stock in the ground [18] and possibly lead to soil depletion due to the exportation of the minerals from the residues [19]. IFN (Inventaire Forestier National) estimated that around $1950 \mathrm{kt}$ of unexploited dry wood residues are available each year in Lorraine [20]. More recently, Renaud [21], from ONF Lorraine, pointed out that to avoid soil depletion, only residues larger than $7 \mathrm{~cm}$ should be exploited. Such a consideration limits the available biomass stock for energetic use to around $100 \mathrm{kt}$ each year. According to [20], this figure could reach 500 dry kt if private forests were taken into account. To ensure sufficient feedstock, wood residues can also be exploited around Lorraine, in Champagne Ardennes or Franche-Comté for example - two neighbouring regions - where more than 580 kt of dry wood residues bigger than $7 \mathrm{~cm}$ should be available [20]. Therefore, despite the current demand on the wood market by other industries, it appears that the available resource 
in woody biomass could be sufficient in the region or extended region to fulfil the needs of the plant.

\section{Crop residues}

We considered the residues from crop farming with relatively low ash content, namely wheat or barley straw. In France, these residues are usually used either as cattle food, as bedding for manure or they are simply left on the field in swaths to fertilize the soil. Using the amount usually left on the field as an energy feedstock could result in soil depletion in nutrients and carbon, requiring the use of fertilizer, but also in several indirect impacts such as erosion or decrease in food source and habitat for soil biota. But conversely, as explained for wood residues, crops residues exploitation is an interesting option to optimize the land utilization. The amount of those which could be available for an energetic use greatly varies according to sources, e.g. from 700 [22] to $10000 \mathrm{kt} \mathrm{[23]} \mathrm{for} \mathrm{France,} \mathrm{and} \mathrm{to} \mathrm{the} \mathrm{price} \mathrm{offered.} \mathrm{Besides,} \mathrm{the}$ transportation costs may be quite high because of the very low energy density of the straw. An alternative could consist of densifying the straw before its transportation, with technologies like small units of pelletisation or bio-slurry production [24]. However, because such processes would significantly increase the overall cost, these were not retained in the study. For this reason straw supply should be restricted to a very limited area around the plant. According to the previous remark and because of the scattering of the available data on straw feedstock, we decided to calculate the potential straw feedstock in Lorraine on the basis of the yearly production of wheat and barley in Lorraine. The production of straw was assessed from straw yields - tons of straw per ton of grain - found in the literature. According to the report of the agricultural cooperative CAL [25], $400 \mathrm{kt}$ of wheat and barley are produced each year in the area (within $150 \mathrm{~km}$ ) of the plant. Considering that wheat or barley straw yield lies between 0.5 and $0.9 \mathrm{t}$ of straw per ton of grain, and that only a third of the production could be used as an energy feedstock, between 65 and $120 \mathrm{kt}$ of straw per year would be available around the plant. For an extended area (whole region of Lorraine), a similar calculation leads to 430-790 kt of straw available each year [26].

Another important product of the farming sector in France is wheat brans and oat hulls, with $19000 \mathrm{kt}$ produced each year. However, due to its high protein content almost the entire feedstock is already used for animal food. Moreover, its cost would be prohibitive for energetic use. We therefore excluded it from our study.

To conclude on the farming residues, only straw was kept as a relevant biomass resource, as it is available in sufficient amount for producing biochar fines or torrefied biomass fines. Nevertheless, it should be kept in mind that the chemical composition of the straw must be carefully looked at, since it may contain undesirable elements such as sodium and potassium in high proportion.

\section{Energy crops}

In Europe, energy crop typically consist of lucerne, miscanthus and switchgrass. Those three types of crops are not enough developed in France to be considered as part of the substitution scenarios. In addition to those types of crops, poplar and willow, which are short rotation coppice may also be considered. In fact, these were already taken into account in the woody biomass section, as they were counted as forests material in the figures from IFN. In addition their yearly production is quite low in Lorraine, the main production being done in the South of France [20]. 


\section{Wastes from the food processing industry}

In France, food-processing industry (including cattle farming) produces around $4600 \mathrm{kt}$ (dry) of wastes, including $2600 \mathrm{kt}$ of sludges and $800 \mathrm{kt}$ of organic wastes [27]. $47 \%$ of the sludges and effluents and $15 \%$ of the organic wastes are not valorised and could be potentially available. In Lorraine, about $65 \mathrm{kt}$ (dry) of sludges and effluents and $10.8 \mathrm{kt}$ (dry) of organic wastes were produced in 2008 [28]. Considering that the ratios nationwide and regionwide are similar, it can be estimated that around $30 \mathrm{kt}$ (dry) of sludges and effluents and only a few kt of organic wastes would be available in the region. Due to the low availability of this kind of biomass, its high heterogeneity and its high moisture content, it was not considered further in this study. In addition this kind of feedstock is more likely to be used for biogas production, which was not reviewed in this paper.

\section{Charcoal}

Charcoal is an interesting biomass product, as it has already been pretreated so that no or few additional processing is required. In France its production is mainly aimed at households or catering and reaches around $50 \mathrm{kt} / \mathrm{yr}$. This amount is not enough to fulfil the national demand, around $100 \mathrm{kt}$, and the main producers and suppliers have to import the missing $50 \mathrm{kt}$ from Eastern countries. Although there is not enough charcoal lumps produced locally for now, part of the available wood feedstock could be dedicated to additional charcoal production and allow a small substitution rate. In addition, charcoal producers also produce small amounts of charcoal fines, mostly because of charcoal handling, which could be used for tuyere injection. Finally the charcoal market is sufficiently developed worldwide to ensure easy importations. For those reasons charcoal was part of the selected scenarios.

\section{Selecting the scenarios}

The confrontation among technical requirements, feedstock demand for $20 \%$ substitution and biomass availability leads to a first selection of scenarios, listed in Table 5. All those scenarios could be implemented in the considered plant, located in Lorraine. However, for sake of simplicity, only woody biomass will be discussed in the remaining of the present paper. Other types of biomass need further studies.

For greater substitution rates, $50 \%$ for example, we can notice that the local biomass feedstock would not be sufficient. Indeed, for instance, the whole amount of wood residues or of straw available would have to be used to supply the considered production site, to the detriment of any other use.

Regarding a broader use of biomass in Europe, European availability of wood residues and straw was roughly assessed to respectively $29,5 \mathrm{Mt} / \mathrm{y}$ and 46 to $83 \mathrm{Mt} / \mathrm{y}$ according to FAO statistics [29]. A comparison between these figures and the needs indicated in Table 4 shows that such a wide use of biomass in Europe would not be possible, and only smaller scale use, such as the case studied here, would be reasonable.

\section{GHG implications of the selected scenarios}

In order to grade the scenarios on the basis of their GHG load, the scenarios were first compared to each other and to the classical route through a screening GHG footprint assessment. For this basic GHG footprint assessment, a cradle-to-gate approach, from the production of the fossil, mineral and renewable feedstock to the final product, liquid iron, was adopted. The system includes all main processes of the classical route (blast furnace, sintering 
plant, coking plant), as well as transportation, coal and iron ore mining operation, biomass exploitation and biomass pre-treatment processes. The functional unit adopted is the production of one metric ton of liquid iron.

\section{Assumptions}

The main hypotheses for this screening GHG footprint assessment are summarized below:

- inventories come from literature or from simple models of the processes, based on mass and energy balances,

- only greenhouse gas (GHG) emissions were looked at,

- impacts of infrastructures are supposed negligible,

- only main processes, listed above, were considered (secondary processes were not included),

- in each alternate scenario of substitution for coke in the blast furnace, $20 \%$ of the coke was replaced; for substitution at the sintering plant, the whole anthracite content is replaced with biomass (charcoal), which represents around $50 \%$ of the energy input,

- only woody biomass was considered: cases 1, 2, 3, 4 and 7 from Table 5.

In addition, we considered that the exhaust gases of all processes - the blast furnace, coking plant and biomass pre-treatment processes - are completely and ideally burnt to form $\mathrm{H}_{2} \mathrm{O}$ and $\mathrm{CO}_{2}$ released into the atmosphere. In the case of the blast furnace and the coking plant, electrical power is generated with the energy released by the combustion of exhaust gases, using a boiler and a turbine, whose yield was estimated to $35 \%$. The electricity produced from the blast furnace gases is usually entirely consumed in the plant itself, for downstream operations. Thus, from a global point of view, this internal power generation results in a mitigation of the electricity consumption of the plant from the grid. However, as our functional unit has been defined as one ton of liquid iron, the system does not include downstream operations. Accordingly the electricity used by those operations should not be considered and the electricity produced in the plant should be counted as a net exportation, which results in net emissions credits. Those credits are calculated on the basis of the avoided electricity production from the French grid-mix. At the coking plant, whose location may be in different places in Europe since coke is purchased on the European market, the production of electricity from the combustion of the exhaust gases will result in emissions credits, based this time on the European grid-mix.

Note that the following items were not taken into account in the screening GHG footprint assessment: (i) yield dependence on the biomass feed for the pre-treatment processes; (ii) secondary inputs (olivine, limestone); (iii) geographical dependence of the pre-treatment processes efficiency.

\section{Transportation}

When GHG issues are addressed, environmental load of transportation has to be carefully accounted for. In our study, it raises the question of the origin of the biomass. If only road transportation is concerned, the closer the biomass, the more economic and environmentally friendly the solution, but the local area may not be able to fulfil the demand in terms of quantity. At the same time, long distance transport by ship or train could compete with medium-distance transportation by truck to a certain extent [30]. Accordingly four potential "origins" for the biomass may be considered: local $(30-50 \mathrm{~km})$, regional $(50-300 \mathrm{~km})$, national and international. For each origin, different transportation means have to be considered: mainly trucks for small distances, trains and trucks for larger distances (national 
scale) and a mix of trains, trucks and ships for international transportation. Another important aspect regarding the transport issue is the energy density of the transported feedstock. From an environmental and an economical point of view, high energy density biomass can be transported on greater distances than low energy density biomass. For this reason, for long distances, it could be relevant to process the biomass before its transportation in order to increase its energy density.

Accordingly, we decided to consider, in our calculations, that the raw biomass was produced regionally, with an average transportation distance of $100 \mathrm{~km}$, and that the biomass is processed directly on the site prior its utilization.

\section{Hot spots}

Fig. 1 shows the main results of the screening GHG footprint assessment, for the reference case (i.e. the normal practice of the plant, using fossil fuels) and two scenarios of substitution with charcoal, loaded at the top or injected through the tuyeres. The bars in plain greys represent the anthropogenic emissions, and the empty ones the biogenic $\mathrm{CO}_{2}$ stemming from the combustion or the pyrolysis of the biomass. This biogenic $\mathrm{CO}_{2}$ is not counted as a GHG, but it is reported on the graph for information. To complete our remarks on the electricity produced at the blast furnace and at the coking plant, we also chose to represent the emissions or credits linked to the use or the production of electricity. Those are showed by the doted bars.

As expected, the main source of GHG for each scenario is the blast furnace, corresponding to about $70 \%$ of the whole GHG emissions. Biomass pretreatment comes next, but more than $98 \%$ of these emissions are biogenic. Indeed, in the case of carbonization, more than $50 \%$ of the carbon content of the biomass will be released during the process in the form of gases (including $\mathrm{CO}_{2}$ ) and tars. Biomass pretreatment is therefore almost carbon neutral.

The screening also shows that the substitution for $20 \%$ of the coke in the blast furnace can only result in an overall $14.7 \%$ reduction in GHG emissions.

Coking plant emissions in biomass scenarios are reduced by almost $19 \%$, somewhat below the expected $20 \%$ because the coke oven also produces coke for the sintering process whose demand is not affected in these two cases with biomass. Concerning the emissions of the other processes, only minor changes occur. The greenhouse gas emissions from the extraction steps is slightly reduced as less coal has to be mined, but the extent of the reduction is then less than $0.5 \%$ of the total GHG emissions. This gain is largely overcome by the emissions associated with the plantation step (around $0.7 \%$ ). The transportation step is hardly increased $(0.2 \%$ of the total GHG emissions). Main transportation emissions come from the supply of iron ore from Brazil, supplied in huge quantities over a long distance. The sintering step is virtually not affected by the biomass substitution in the blast furnace.

The slight differences between the use of charcoal at the top or at the tuyeres, is explained by the replacement ratio of coke by charcoal: pulverized charcoal injected at the tuyeres has a better replacement ratio than lumps loaded at the top (0.74 and 0.67 respectively). As a consequence, in the lumps case more charcoal has to be produced and transported resulting in extra emissions during plantation, pretreatment and transportation steps. However these extra emissions are quite low compared to the amount of $\mathrm{CO}_{2}$ emitted in the process.

\section{Overall $\mathrm{CO}_{2}$ reduction potential of the scenarios}

In order to compare the different scenarios, we calculated their global greenhouse gas emissions. Because the fast pyrolysis to produce bio-oil also produces a significant amount of biochar, which can be handled as a byproduct, the bio-oil case is presented separately in the 
next section. Fig. 2.a shows the total GHG emissions for the classical route and four substitution scenarios and the corresponding GHG reduction compared with the classical route reference are reported in Fig. 2.b. Credits from electricity exportation are deduced and biogenic emissions are of course not accounted for.

First, it must be noticed that substitution at the sintering plant is less efficient than the other scenarios from an overall point of view. This can easily be explained as the amount of fuel used at this stage is relatively low, which results in low benefit despite a high substitution ratio (around $50 \%$ of the fuel consumption) in this unit. On a specific basis, however, the efficiencies of the substitutions at the sintering plant or at the blast furnace are approximately the same. The GHG offset per unit of fuel replaced is $3.13 \mathrm{~kg} \mathrm{CO}_{2} / \mathrm{t}$ of anthracite at the sintering plant against $3.2 \mathrm{~kg} \mathrm{CO} / \mathrm{t}$ coke for charcoal fines injection in the blast furnace. Moreover there is some evidence of significant reduction in $\mathrm{NO}_{\mathrm{x}}$ and $\mathrm{SO}_{\mathrm{x}}$ with wood char replacement of coke breeze in sintering [8] which may in turn lower $\mathrm{CO}_{2}$-equivalent for sintering with charcoal.

Second, it appears that for the same level of substitution (20\%), charcoal lumps, charcoal fines and torrefied biomass approximately reach the same ratio of $\mathrm{CO}_{2}$ reduction: $15 \%$. The slight difference between charcoal and torrefied biomass is mainly explained by the fact that a larger amount of biomass has to be produced for charcoal use due to a lower yield at carbonization than at torrefaction. Accordingly, plantation and transportation steps should emit slightly more. Data about $\mathrm{N}_{2} \mathrm{O}$ emissions in carbonization were taken from [31] and assumed the same for torrefaction, for which no specific data were found. Indeed, greater $\mathrm{N}_{2} \mathrm{O}$ emissions would be expected in the carbonization process than in torrefaction, because a longer residence time in pyrolysis reactor would imply greater nitrogen releases and a greater production of $\mathrm{N}_{2} \mathrm{O}$ as well.

\section{Bio-oil scenario}

The industrial process considered for bio-oil production is the process patented by Dynamotive. This process produces a bio-oil with a high water content, together with a solid byproduct called biochar. Around 15 to $20 \%$ of the biomass entering the process is converted into biochar, which is mainly made of carbon $(73 \%)$ and whose LHV is around $26 \mathrm{MJ} / \mathrm{kg}$. Because of its high water content the bio-oil exhibits a low LHV, around $16 \mathrm{MJ} / \mathrm{kg}$, which directly leads to a very low replacement ratio in the framework of our study. To reach $20 \%$ substitution for coke in the blast furnace would create a significant demand in bio-oil and a large amount of biochar would be produced at the same time. To handle this by product in GHG emission calculations, the system expansion approach was adopted. Depending on the way this biochar is used, inside or outside the boundaries of our system, results of the bio-oil scenario in terms of GHG emissions are significantly affected. Four cases were considered, as shown in Fig. 3 together with the relevant figures of the system expansion.

As an energetic product, this biochar could probably be directly injected into the blast furnace at the tuyeres together with bio-oil (case A). In that case, less bio-oil would have to be produced in order to replace the same amount of coke since biochar would replace a part of the coke as well. This option would certainly be the easiest way to use this biochar, provided its injection at the tuyeres together with the bio-oil is technically possible. Note that this biochar could not be used as a direct replacement in the sintering step because of its small size (less than $1 \mathrm{~mm}$ ). In that case, and for 1 ton of bio-oil produced, $185 \mathrm{~kg}$ of coke could be saved, resulting in a $\mathrm{CO}_{2}$-equivalent credit of $585 \mathrm{~kg}$.

Another possible option (case B) would be to produce electricity from this biochar for internal use and/or exportation to the grid. For the Lorraine plant considered, there are very limited possible internal uses and the electricity would be exported to the French national electricity grid, which would result in an emission credit of $55 \mathrm{~kg}$ of $\mathrm{CO}_{2}$-equivalent for 1 ton of bio-oil. 
If the bio-oil was produced off-site in EU and the resulting biochar used for power production (case $\mathrm{C}$ ), the emission credit could reach up to $307 \mathrm{~kg} \mathrm{CO}_{2}$-equivalent per ton of bio-oil produced.

If no energetic valorisation were chosen the biochar would probably be used as soil amendment (case D). After soil amendment, according to Hammond et al. [32], around $68 \%$ of the carbon contained in the biochar can be assumed to remain stable and stored in the ground for a time horizon of 100 years, resulting a net $\mathrm{CO}_{2}$ sink. The rest is considered to be released as $\mathrm{CO}_{2}$ within the next hours or years. The corresponding credit is high, $455 \mathrm{~kg}$ of $\mathrm{CO}_{2}$-equivalent.

Fig. 4 compares the impacts of bio-oil production $\left(\mathrm{kg} \mathrm{CO}_{2}\right.$-equivalent per ton of bio-oil produced) for the four biochar applications. It shows that the sum of the emissions related to the production of bio-oil ( $84 \mathrm{~kg} \mathrm{CO}_{2}$-equivalent) plus those related to the biochar valorisation process are much lower (in cases $\mathrm{A}, \mathrm{C}$ and $\mathrm{D}$ ) than the $\mathrm{CO}_{2}$ credits corresponding to the avoided emissions.

Fig. 5 shows the overall GHG reduction potential over the whole system (ironmaking with bio-oil compared to the classical process) for the four scenarios of biochar use. Cases B, C, and $\mathrm{D}$ correspond to the same (high, around $783 \mathrm{~kg}$ ) amount of bio-oil needed for substitution for $20 \%$ of the coke. Their merit is ordered like in Fig. 4, the best result being obtained with biochar used as soil amendment (case D), followed by off-site (C) and on-site (B) power production. When biochar is valorized in the BF, we first considered the case where bio-oil $(419 \mathrm{~kg})$ and associated biochar $(106 \mathrm{~kg})$ together replace $20 \%$ of the coke (solid bar of case A). The GHG reduction (13.9\%) is then similar to that of case B and lower than that of cases C and D. However, to complete the picture and to compare the four scenarios based on the same amount of bio-oil produced, we also considered an alternate scenario where in addition to the substitution of bio-oil for $20 \%$ of the coke, the associated biochar produced would also be injected in the blast furnace. This last scenario is represented by the dotted bar over the case A in Fig. 5. In that case, the coke substitution rate would reach around $50 \%$ and up to $30.2 \%$ reduction of GHG could be achieved. Lastly, when compared with each of the other scenarios (Fig. 2), the reduction potential of the injection of the biochar in the blast furnace (case A) is lower than with the charcoal lumps or charcoal fines scenarios. This is because more biomass has to be produced, transported and pyrolysed, leading to more anthropogenic emissions.

Finally, GHG aspects are not the only concern; one should also take into account economical consequences. Considering the huge amount of bio-oil required and its production cost in France, it is anticipated this would require an increased level of support to make it an economical interest. The economical evaluation of each biomass scenario is reported below.

\section{Cost evaluation}

In order to compare the economical viability of the various scenarios, a rough cost evaluation was performed. Four parameters have been considered: the price of the pretreated biomass delivered, the price of delivered coke, the replacement ratio, and the $\mathrm{CO}_{2}$ cost. The first three parameters are known or can be estimated from the literature. The price of coke is volatile and we considered a range of prices representative for 2011 market prices [33]. The $\mathrm{CO}_{2}$ cost evaluation is trickier. As the regulation concerning $\mathrm{CO}_{2}$ quota in Europe is about to change and will surely lead to higher $\mathrm{CO}_{2}$ prices, $30 €$ is probably a reasonable estimation of what could be the price of $\mathrm{CO}_{2}$ in 2013 with the new regulation. To cover the case where $\mathrm{CO}_{2}$ cost were to increase more than expected, we considered $\mathrm{CO}_{2}$ prices from 30 to $60 € / t \mathrm{CO}_{2}$. The $\mathrm{CO}_{2}$ tax from a legal point of view is based on a carbon mass balance restricted to the production site only. Accordingly, in our case the carbon balance was carried out for the iron 
plant only, which includes the blast furnace and the sintering plant. Of course, biogenic $\mathrm{CO}_{2}$ is not accounted for.

The extra cost associated to the substitution for $20 \%$ of the coke in the blast furnace (or to the substitution for $50 \%$ of the coal at sintering) for the production of one ton of liquid iron is calculated for each scenario as follows.

$$
\text { Cost }=S R \cdot C I \cdot\left(\frac{P_{\text {biomass }}}{R R}-P_{f u e l}-P_{\mathrm{CO} 2} \cdot E F_{\text {fuel }}\right)
$$

with

$\mathrm{P}_{\text {fuel }}=$ Estimated price of coke or coal $=290$ to $355 € / \mathrm{t}$ coke and $150 € / \mathrm{t}$ coal

$\mathrm{P}_{\text {biomass }}=$ Price of pre-treated biomass

$\mathrm{RR}=$ Replacement ratio

$\mathrm{P}_{\mathrm{CO} 2}=30$ to $60 € / \mathrm{t} \mathrm{CO}_{2}$

$\mathrm{EF}_{\text {fuel }}=\mathrm{CO}_{2}$ emission coefficient for coke or coal $=3.16 \mathrm{t} \mathrm{CO}_{2} / \mathrm{t}$ coke or coal

$\mathrm{SR}=$ Substitution ratio $=20 \%$ in the blast furnace, $50 \%$ at the sintering plant

$\mathrm{CI}=$ Coke/Coal input, $0.47 \mathrm{t}$ coke/t HM in the blast furnace, 0.096 at the sintering plant

Results (Table 6) show that the bio-oil scenario, even with the use of biochar in the blast furnace, appears to be an unacceptably expensive solution, because of the low replacement ratio of bio-oil. From an economical point of view, the injection of carbonized fines in the blast furnace tuyeres seems to be the best solution with savings up to $9.9 € / t$ of liquid iron produced with a price of coke around $355 € / \mathrm{t}$ and a $\mathrm{CO}_{2}$ cost of $60 € / \mathrm{t}$. The injection of torrefied biomass comes second, with a cost of $10.1 € / \mathrm{t}$ liquid iron $\left(\mathrm{CO}_{2}\right.$ at $30 € / \mathrm{t}$ and coke at $290 € / t)$ and a saving of $5 € / t$ of liquid iron in the best case. Finally, the charcoal lumps loaded at the top result in a loss of $13.4 € / \mathrm{t}$ of liquid iron produced in the worst case, and $1.7 €$ of savings in the best case. The use of charcoal or biochar in the sinter plant is a special case: the fuel that is replaced is no longer coke but coal (anthracite), a fuel that is much cheaper than coke, which explains why this scenario is not cost-effective.

Finally, we calculated the cost the ton of $\mathrm{CO}_{2}$ should reach to make the biomass solutions neutral (last line of Table 6). From our calculations, biomass use becomes economical for $\mathrm{CO}_{2}$ costs above $26.6 € / \mathrm{t}$ in the best case (charcoal fines at blast furnace).

\section{Conclusions}

We considered and evaluated the possibilities of replacing a part $(20 \%)$ of the fossil fuels used for pig iron production with renewable biomass, in the case of an ironmaking plant located in Lorraine, France. Different types of biomass and their uses in the ironmaking process were considered and evaluated to establish process and quantities requirements in order to draw a short list of plausible scenarios. Only two types of solid biomass, namely wood and crop residues, were able to fit all the requirements of the particular case of our study. Because of the physical characteristics and the insufficient calorific value of these two raw biomasses, these would have to undergo a pretreatment step before being used in the ironmaking process, either carbonization or torrefaction at high temperature to produce solid char with properties similar to fossil coal. Carbonized biomass can be used as lumps loaded at the blast furnace top, as mid-size fines in the sintering plant, and as pulverized powder through the blast furnace tuyeres. Torrefied biomass could be used as a pulverized powder injected through the tuyeres.

A screening GHG footprint assessment showed that from a GHG emission point of view using torrefied and pulverized biomass in the blast furnace would be the most environmentally friendly scenario, with $14.7 \% \mathrm{CO}_{2}$-equivalent reduction, followed closely by pulverized biomass char injection and charcoal lumps loaded at the top of the furnace, with $14.5 \%$ and $14.4 \% \mathrm{CO}_{2}$-equivalent reduction, respectively. Replacing all the anthracite used 
at the sintering plant with biomass char resulted in a $6.7 \% \mathrm{CO}_{2}$-equivalent reduction. Finally, the use of bio-oil was also investigated, raising the issue of biomass byproducts and their optimum utilization. Our analysis suggests that among the different possible uses of biochar, the bio-oil byproduct, soil amendment use would provide the highest $\mathrm{CO}_{2}$-equivalent reduction. More generally, further dedicated studies should be carried out to determine the best use for biomass residues among steelmaking and other applications.

Economically, considering the feedstock and preparation costs, as well as the estimated charged $\mathrm{CO}_{2}$ cost, the injection of charcoal fines at tuyeres is the most cost-effective solution and is likely to increase profits, closely followed by torrefied and pulverized biomass at tuyeres. With a price at $30 € / \mathrm{t}$ of $\mathrm{CO}_{2}$, replacing $20 \%$ of the coke by injecting charcoal fines through the tuyeres is anticipated to offset $14.7 \%$ of the hot metal plant GHG and increase profitability by $3.4 € / t$ of steel.

As suggested in the introduction, the next step of our work will be to perform a full LCA to take into account other impacts than GHG emissions and to evaluate more accurately the environmental implications of the biomass use for ironmaking.

Acknowledgements: the authors thank Saint-Gobain PAM and Agence Nationale de la Recherche et de la Technologie for their financial support.

\section{References}

1. IEA: Sectoral approaches to greenhouse gas mitigation - Exploring Issues for Heavy Industry. International Energy Agency, Paris, (2007)

2. European Commission: 2007/589/EC: Commission decision of 18 July 2007 establishing guidelines for the monitoring and reporting of greenhouse gas emissions pursuant to Directive. Official Journal of the European Union (2007).

3. Norgate T.E., Langberg D.: Environmental and Economic Aspects of Charcoal Use in Steelmaking. ISIJ Int. 49(4), 587-595 (2009).

4. Wing Ng K., Giroux L., MacPhee T., Todoschuk T.: Combustibility of Charcoal for Direct Injection in Blast Furnace Ironmaking. Association for Iron \& Steel Technology (2012).

5. Mathieson J.G., Rogers H., Somerville M.A., Jahanshahi S., Ridgeway P.: Potential for the use of biomass in the iron and steel industrie. In: Chemeca 2011, Syndey, Australia, 18-21 septembre 20112011

6. Matsumura T., Ichida M., Nagasaka T., Kato K.: Carbonization behaviour of woody biomass and resulting metallurgical coke properties. ISIJ Int. 48(5), 572-577 (2008).

7. Macphee J.A., Gransden J.F., Giroux L., Price J.T.: Possible CO2 mitigation via addition of charcoal to coking coal blends. Fuel Process. Technol. 90, 16-20 (2009).

8. Lovel R., Vining K., Dell'Amico M.: Iron ore sintering with charcoal. Miner. Process. Extr. Metal. 116(2), 85-92 (2007).

9. Lovel R., Vining K., Dell'Amico M.: The Influence of Fuel Reactivity on Iron Ore Sintering. ISIJ Int. 49(2), 195-202 (2009).

10. Guivarch A.: Valeur fertilisante à court terme du phosphore des boues de stations d'épuration urbaines. INPL (2001)

11. M.C., L.: Canne de maïs ensilée. L'institut de l'élevage, (2003)

12. US Department of Energy: Biomass Feedstock Composition and Property Database. http://www1.eere.energy.gov/biomass/databases.html (2004). 
13. Mohan D., Pittman C.U., P.H., S.: Pyrolysis of Wood/Biomass for Bio-oil: A Critical Review. Energy Fuels 20, 848-889 (2006).

14. Bergman P.C.A., Boersma A.R., Kiel J.H.A., Prins M.J., Ptasinski K.J., F.J.J.G., J.: Torrefaction for biomass upgrading. In: European Biomass Conference \& Exhibition, Paris, France, 17-21 October 20052005

15. Norgate T., Haque N., Somerville M.A., Jahanshahi S.: Biomass as a source of renewable carbon for iron and steelmaking. ISIJ Int. 52(8), 1472-1481 (2012).

16. European Parliament: Les forêts de l'union européenne. http://www.europarl.europa.eu/workingpapers/agri/s4-1-1_fr.htm (1996).

17. Agreste, Ministère de l'agriculture de l'alimentation de la pêche de la ruralité et de l'aménagement du territoire: Récolte de bois et production de sciages en 2008. Agreste Chiffres et Données Agroalimentaires(170) (2010).

18. Palosuo T., Wihersaari M., Liski J.: Net greenhousegas emissions due to energy use of forest residues - Impact of soil carbon balance. In: Woody biomass as an energy source - Challenges in Europe, Joensuu, Finland, 25-28 septembre 20002000

19. ADEME: La récolte raisonnée des rémanents en forêt. (2008).

20. IFN, ADEME, Solagro: Evaluation du potentiel Bois Energie. (2004)

21. Renaud, J.P.: Innovations dans la gestion des marchés: les contrats d'approvisionnement. In: Forêt-bois: quelles ressources pour quels produits? Nancy 2011

22. ADEME, ITCF: Résidus de culture: paille de céréales. ADEME, ITCF, Paris, (1998)

23. Sourie J.C.: Les pailles de céréales, ressources, valorisations, obstacles à leur mobilisation. In: Chimie verte: questions à la recherche, Paris 2006

24. Raffelt K., Henrich E., Koegel A., Stahl A., Steinhardt J., Weirich F.: The BTL2 Process of Biomass Utilization Entrained-Flow Gasification of Pyrolyzed Biomass Slurries. Appl. Biochem. Biotechnol. 129, 153 - 164 (2006).

25. CAL: Agriculture en Lorraine. http://cralorraine.fr/index.php?page $=060 \&$ rubrique $=$ Productions\%20agricoles (2010).

26. Guillin S.: Les grandes cultures en Lorraine - Récolte 2011. DRAAF, Metz, (2011)

27. Agreste: Déchets des industries agroalimentaires selon le type de déchet et la région en 2008. Agreste Primeur, vol. 245. Agreste Primeur, (2010)

28. Agreste, INSEE: Enquête sur la production de déchets non dangereux dans l'industrie en 2008. Agreste, Montreuil sous bois, (2010)

29. FAO: FAOSTAT. (2012)

30. Börjesson P.I.I.: Emissions of $\mathrm{CO} 2$ from biomass production and transportation in agriculture and forestry. ECM 37(6-8), 1235-1240 (1996).

31. Pennise D. M., Smith K. R., Kithinji J. P., Rezende M. E., Raad T. J., Zhang J., Fan C.: Emissions of greenhouse gases and other airborne pollutants from charcoal making in Kenya and Brazil. JGR 106(24), 143-155 (2001).

32. Hammond J., Shackley S., Sohi S., P., B.: Prospective life cycle carbon abatement for pyrolysis biochar systems in the UK. Energy Policy 39, 2646-2655 (2011).

33. Steelonthenet: Metallurigcal coke prices - Europe 2008-2012. http://www.steelonthenet.com/files/blast-furnace-coke.html (2012). Accessed $27 / 04 / 2012$ 


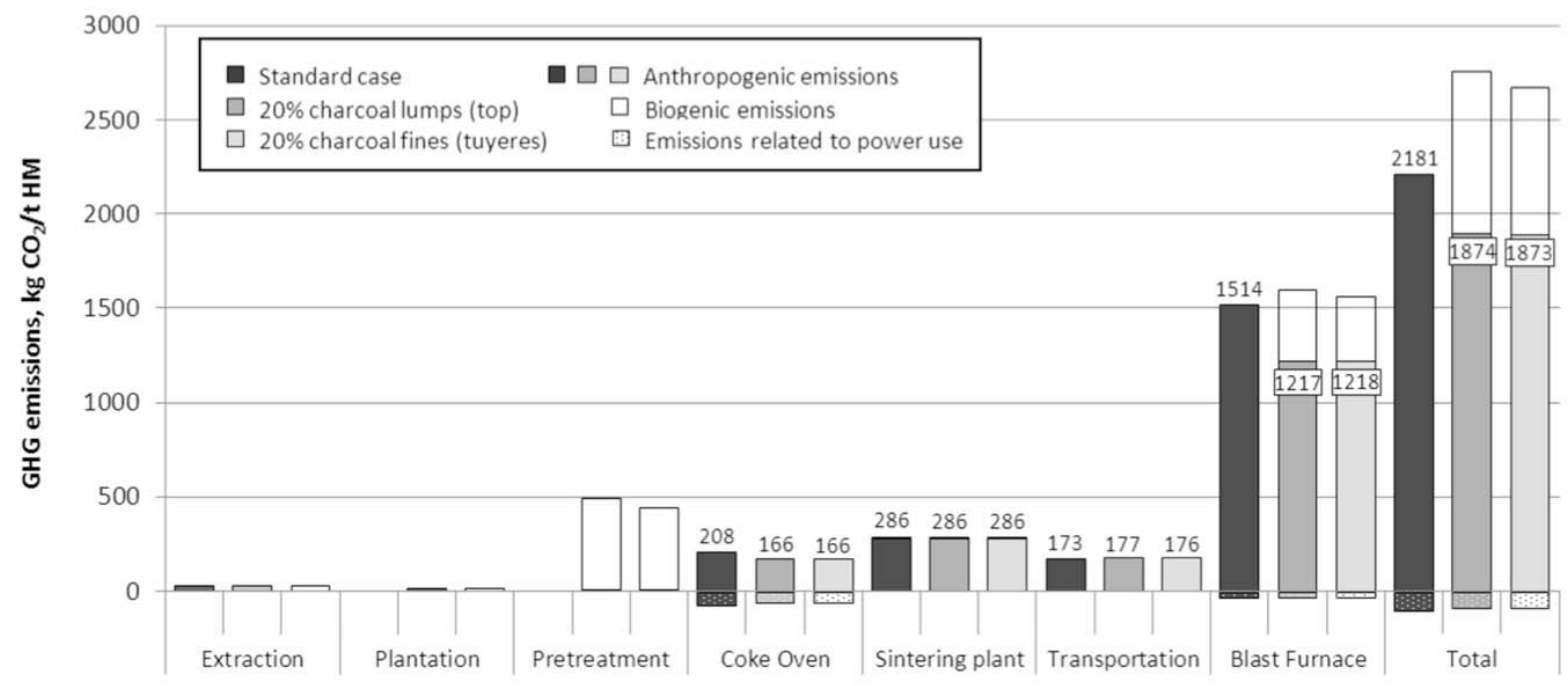

Fig. 1 Comparison among the reference case (black) and two scenarios of substitution at the blast furnace: charcoal loaded at the top (dark grey) and injected through the tuyeres (light grey). HM means Hot Metal (liquid pig iron).
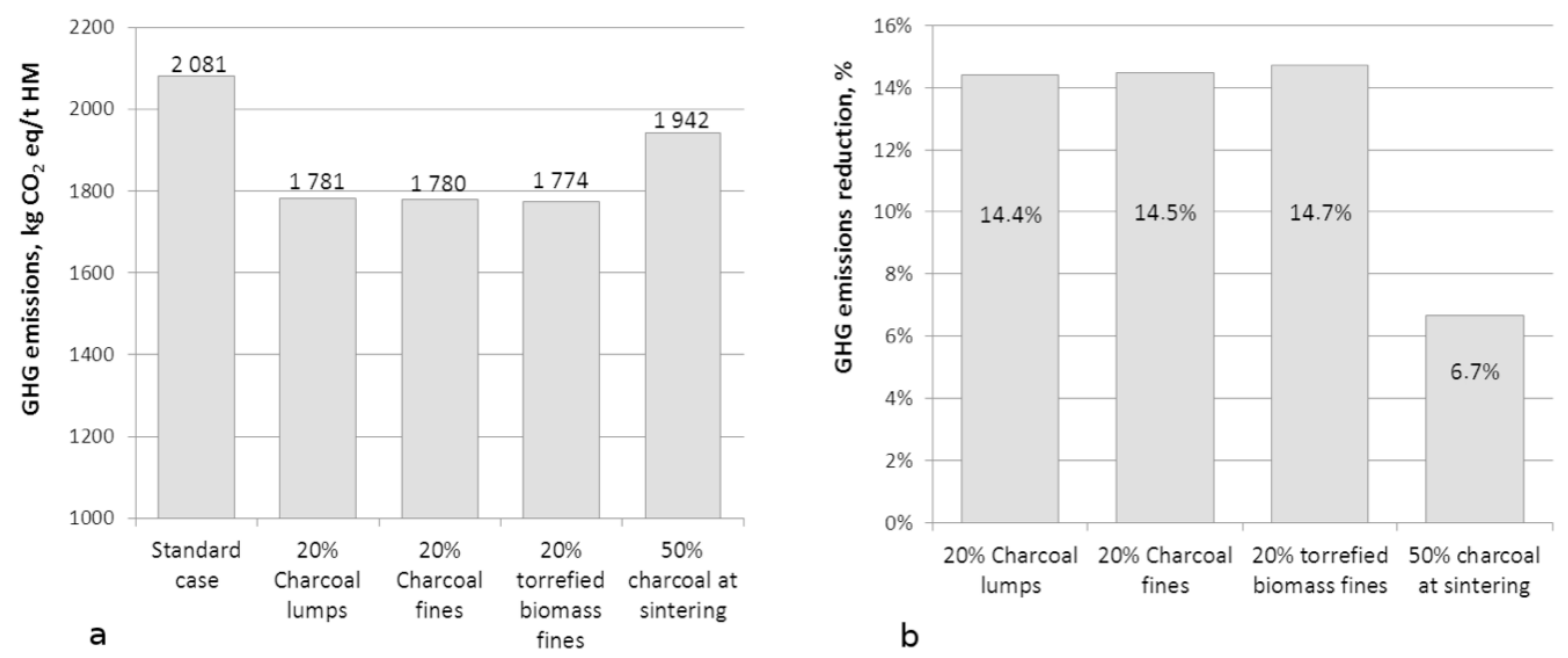

Fig. 2 Comparison among the different selected scenarios, a. Total greenhouse gas emissions in $\mathrm{kg} \mathrm{CO}_{2} \mathrm{eq} / \mathrm{t}$ liquid iron, and b. Emission reduction with regard to classical route. 


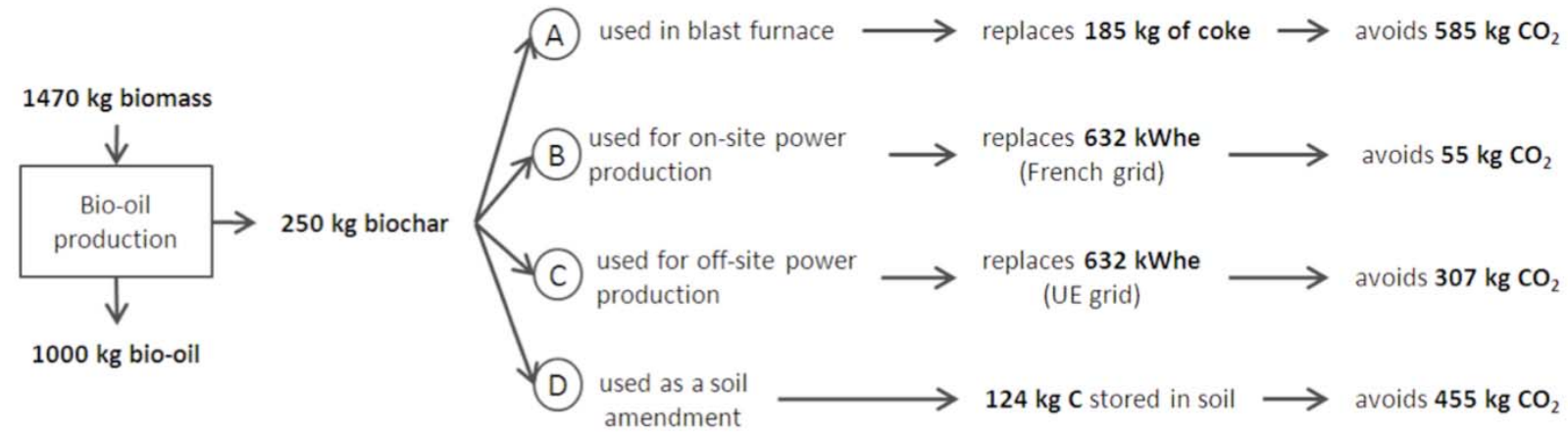

Fig. 3 Scenarios of bio-oil production considering four applications for the biochar.

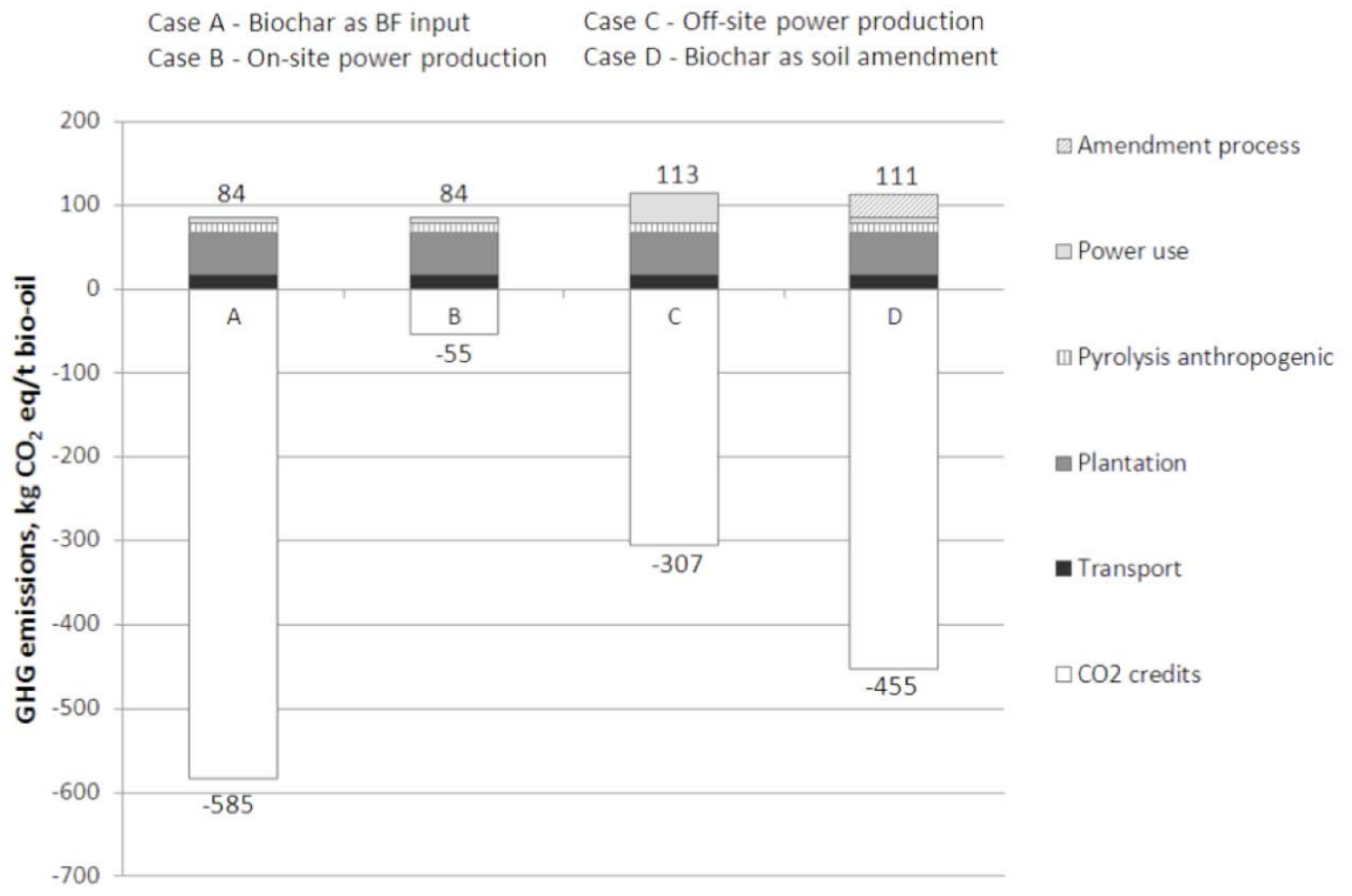

Fig. 4 GHG emissions and credits associated to the production of 1 ton of bio-oil, for the four biochar applications. 


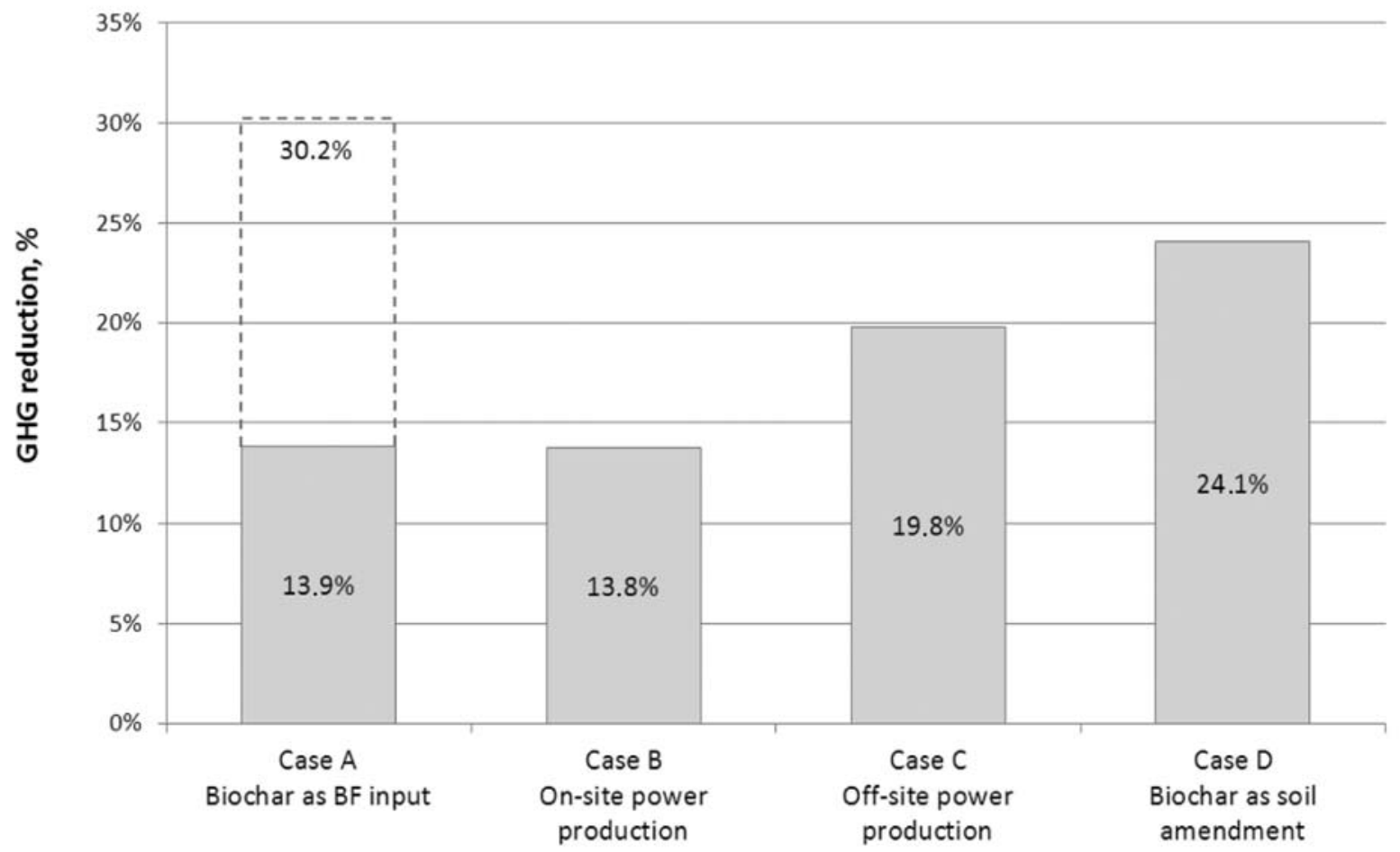

Fig. 5 GHG reduction potential over the whole route for the four bio-oil cases ( $1 \mathrm{t}$ liquid iron, $20 \%$ substitution for coke). 


\begin{tabular}{|c|c|c|c|c|c|c|c|c|}
\hline & Units & Wood & Charcoal & Straw & Corn stalk & Sewage sludge & Sinter fuel & BF coke \\
\hline Size & {$[\mathrm{mm}]$} & $0.1-250$ & $20-180$ & $0.1-10$ & n.c. & n.c. & $1-10$ & $50-120$ \\
\hline C content & [\% dry] & $45-50$ & $75-85$ & $45-50$ & $38-48$ & $40-50$ & 84 & 90 \\
\hline Ash content & [\% dry] & $1-5$ & $1-5$ & $2.6-11$ & $5-13.5$ & $10-35$ & 12.5 & $\sim 10$ \\
\hline Zn content & [\% dry] & n.c. & n.c. & n.c. & n.c. & $0.68-1.2$ & n.c. & 0 \\
\hline $\mathrm{K}+\mathrm{Na}$ content & [\% dry] & n.c. & n.c. & n.c. & n.c. & $0.3-4.0$ & $<0.5$ & $<0.35$ \\
\hline P content & [\% dry] & n.c. & n.c. & 0,1 & 0,1 & $0.9-5.2$ & $<0.05$ & $<0.03$ \\
\hline LHV & [MJ/kg dry] & $17-18$ & $27-32$ & $17-18$ & $17-18$ & $12-14$ & 26 & 30 \\
\hline
\end{tabular}

\begin{tabular}{|c|c|c|c|}
\hline & Char & Tar & Gas \\
\hline & [\%] & {$[\%]$} & {$[\%]$} \\
\hline Torrefaction & 87.5 & 11.1 & 1.4 \\
\hline Carbonization & 35 & 30 & 35 \\
\hline Fast pyrolysis & 12 & 75 & 13 \\
\hline Gasification & 10 & 5 & 85 \\
\hline
\end{tabular}

\begin{tabular}{|c|c|c|c|c|c|}
\hline \multirow[b]{2}{*}{ Replacement Ratio } & & & & & \\
\hline & $\begin{array}{c}\text { Charcoal lumps } \\
0.67\end{array}$ & $\frac{\text { Charcoal fines }}{0.74}$ & $\begin{array}{c}\text { Torrefied fines } \\
0.61\end{array}$ & $\frac{\text { Bio-oil }}{0.12}$ & $\frac{\text { Biochar fines at sintering }}{0.9}$ \\
\hline
\end{tabular}

\begin{tabular}{|c|c|c|c|c|c|}
\hline \multicolumn{6}{|c|}{ Table 4-Biomass need for coke replacement in the blast furnaces } \\
\hline \multicolumn{6}{|c|}{ Our study: Lorraine, Saint-Gobain PAM plant } \\
\hline \multirow[t]{2}{*}{ Raw Biomass } & \multirow[t]{2}{*}{ Pre-treated biomass } & \multicolumn{2}{|c|}{$\begin{array}{l}\text { Pre-treated biomass need } \\
\text { [kt/year] }\end{array}$} & \multicolumn{2}{|c|}{$\begin{array}{l}\text { Raw biomass need } \\
\text { [dry kt/year }\end{array}$} \\
\hline & & $20 \%$ & $50 \%$ & $20 \%$ & $50 \%$ \\
\hline Wood lumps & Charcoal lumps & 70.1 & 175.3 & 255.0 & 637.5 \\
\hline Wood residues & Charcoal fines & 63.5 & 158.8 & 230.9 & 577.3 \\
\hline Wood residues & Charcoal fines & 63.5 & 158.8 & 230.9 & 577.3 \\
\hline Solid crop residues & Torrefied biomass fines & 77.0 & 192.5 & 192.5 & 481.3 \\
\hline Solid crop residues & Biochar fines & 63.5 & 158.8 & 230.9 & 577.3 \\
\hline Wood residues & Bio-oil & 379.0 & 947.5 & 557.4 & 1393.5 \\
\hline Solid crop residues & Bio-oil & 379.0 & 947.5 & 557.4 & 1393.5 \\
\hline Solid wastes from FPI & Charcoal fines & 63.5 & 158.8 & 230.9 & 577.3 \\
\hline Solid wastes from FPI & Charcoal fines & 63.5 & 158.8 & 230.9 & 577.3 \\
\hline Solid wastes from FPI & Torrefied biomass fines & 77.0 & 192.5 & 192.5 & 481.3 \\
\hline \multicolumn{6}{|l|}{ Global European case } \\
\hline \multirow[t]{2}{*}{ Raw biomass } & \multirow[t]{2}{*}{ Pre-treated biomass } & \multicolumn{2}{|c|}{$\begin{array}{l}\text { Pre-treated biomass need } \\
\text { [Gt/year] }\end{array}$} & \multicolumn{2}{|c|}{$\begin{array}{l}\text { Raw biomass need } \\
\text { [dry Gt/year] }\end{array}$} \\
\hline & & $20 \%$ & $50 \%$ & $20 \%$ & $50 \%$ \\
\hline Wood residues & Charcoal fines & 34.5 & 86.2 & 125.4 & 313.4 \\
\hline Wood residues & Bio-oil & 205.8 & 514.6 & 302.7 & 756.8 \\
\hline
\end{tabular}


Table 5-List of the case scenarios selected for screening GHG footprint assessment

\begin{tabular}{|cc}
\hline & Biomass \\
\cline { 2 - 2 } 1 & Wood lumps \\
2 & Wood residues \\
3 & Wood residues \\
4 & Wood residues \\
5 & Solid crop residues \\
6 & Solid crop residues \\
7 & Wood residues \\
8 & Solid crop residues \\
\hline
\end{tabular}

\begin{tabular}{c} 
Treatment \\
\hline Carbonization \\
Carbonization + grinding \\
Carbonization + grinding \\
Torrefaction + grinding \\
Torrefaction + grinding \\
Carbonization \\
Fast pyrolysis \\
Fast pyrolysis
\end{tabular}

Product
Charcoal
Charcoal fines
Charcoal fines
Torrefied wood fines
Torrefied biomass fines
Biochar fines
Bio-oil

\begin{tabular}{c} 
Use \\
\hline Top BF \\
Tuyere BF \\
Sintering plant \\
Tuyere BF \\
Tuyere BF \\
Sintering plant \\
Tuyere BF \\
Tuyere BF
\end{tabular}

Table 6-Extra cost associated to biomass substitution, for 1 ton of liquid iron produced

\begin{tabular}{|c|c|c|c|c|c|c|}
\hline \multicolumn{7}{|c|}{ Table 6-Extra cost associated to biomass substitution, for 1 ton of liquid iron produced } \\
\hline \multirow[b]{2}{*}{$\begin{array}{l}\text { Processed Biomass } \\
\text { price }\end{array}$} & & Bio-oil + biochar & $\begin{array}{c}\text { Torrefied } \\
\text { biomass } \\
\end{array}$ & $\begin{array}{c}\text { Charcoal } \\
\text { fines }\end{array}$ & $\begin{array}{c}\text { Charcoal } \\
\text { lumps } \\
\end{array}$ & $\begin{array}{l}\text { Charcoal at } \\
\text { sinter plant }\end{array}$ \\
\hline & {$[€ / t]$} & 330 & 300 & 325 & 350 & 325 \\
\hline Coke/coal price & {$[€ /$ f fuel $]$} & 290 to 355 & 290 to 355 & 290 to 355 & 290 to 355 & 150 \\
\hline $\mathrm{RR}$ & {$[-]$} & 0.19 & 0.61 & 0.74 & 0.67 & 0.9 \\
\hline $\begin{array}{l}\text { Cost for } \mathrm{P}_{\mathrm{CO} 2}=30 € / t \\
\text { Cost for } \mathrm{P}_{\mathrm{CO} 2}=60 € / \mathrm{t}\end{array}$ & $\begin{array}{l}{\left[€ / \mathrm{t}_{\text {liquid iron }}\right]} \\
{[€ / \mathrm{t} \text { liquid iron }]}\end{array}$ & $\begin{array}{l}+121 \text { to }+127 \\
+112 \text { to }+118\end{array}$ & $\begin{array}{c}+3.9 \text { to }+10.1 \\
-5 \text { to }+1.1\end{array}$ & $\begin{array}{l}-1 \text { to }+5.1 \\
-9.9 \text { to }+3.8\end{array}$ & $\begin{array}{c}+7.2 \text { to }+13.4 \\
-1.7 \text { to }+4.4\end{array}$ & $\begin{array}{l}+5.2 \\
+0.9\end{array}$ \\
\hline $\mathrm{P}_{\mathrm{CO} 2}$ for extra cost $=0 €$ & {$\left[€ / t l_{\text {iquid iron }]}\right.$} & 437 to 458 & 43.3 to 63.9 & 26.6 to 47.2 & 54.4 to 75 & 66.8 \\
\hline
\end{tabular}

